\title{
Dental age estimation in brazilian older adults: report of two cases
}

Mário Marques Fernandes ${ }^{\mathrm{a}, \mathrm{b}}$, Alana de Cassia Silva Azevedo ${ }^{\mathrm{b}}$, Alexandre Raphael Deitos ${ }^{\mathrm{c}}$, Maria Gabriela Haye Biazevic ${ }^{b}$, Rogério Nogueira De Oliveira ${ }^{b}$

\section{ABSTRACT}

OBJECTIVE: report two cases of age estimation using the method developed by Kvaal et al. (1995). CASE DESCRIPTION: two males, apparently older and without identity documents, underwent age estimation tests by the Public Ministry in order to estimate chronological age. This method proposes a specific formula for dental elements present with error margin of 11.5 years. After this stage, new civil records were carried out, entitling the cases to some social benefits.

CONCLUSION: age estimation in living individuals is a challenge but significantly important in the civil and penal spheres, and Kvaal's technique may be used in Brazilian older adults.

Keywords: age determination by teeth; radiography; tooth; dental pulp.

\section{Estimativa da idade pelos dentes em idosos brasileiros: relato de dois casos}

\section{RESUMO}

OBJETIVO: relatar dois casos de estimativa de idade com o uso do método de Kvaal et al. (1995). DESCRIÇÃO DO CASO: duas pessoas do sexo masculino, aparentemente idosas e sem documentos de identificação, foram submetidos a exames junto ao Ministério Público visando à estimativa da idade cronológica. Esta metodologia propõe uma fórmula específica para os elementos dentários presentes com uma margem de erro de 11,5 anos. Após essa etapa foram realizados novos registros civis o que possibilitou aos idosos o gozo de alguns benefícios sociais

CONCLUSÃO: A estimativa da idade em indivíduos vivos representa um desafio com significativa importância nos âmbitos civil e penal, e a técnica de Kvaal foi passível de aplicação em idosos brasileiros.

Palavras-chave: determinação da idade pelos dentes; radiografia; dente; polpa dentária. a Serviço Biomédico do Ministério Público do Rio Grande do Sul, Porto Alegre, RS, Brasil

b Departamento de Odontologia Social, Faculdade de Odontologia da Universidade de São Paulo, SP Brasil

${ }^{c}$ Departamento de Polícia Federal, São Paulo, SP, Brasil

Conflict of Interests: The authors state that there Co financial and personal conflicts of interest that could have inappropriately influenced their work.

Copyright: ( 2017 Fernandes et al licensee EDIPUCRS. 


\section{INTRODUCTION}

Age estimation aims to establish the probable age of an individual by assessing somatic aspects and sexual, skeletal, and dental maturity. The purpose of this investigation is to estimate an age interval or mean, since the establishment of an individual's chronological or exact age is a complex task, subject to numerous variables [1].

The literature provides many age estimation methods, which can be divided into skeletal and dental methods. Forensic dentists have developed techniques to estimate the chronological age of children and adults based on the relationship between biological age and characteristics of the dental structure.

Forensic dentists are always looking for the ideal age estimation method. Methods such as aspartic acid racemization and counting of cementum annulations provide the most accurate and precise results. However, such techniques are lengthy, expensive, require dental extraction, and some require the microscopic preparation of dental structures. Additionally, a destructive approach may not be acceptable for ethical, cultural, religious, or scientific reasons [2].

One way to assess someone's age is to consider dental morphological characteristics and physiological deterioration, for example, the deposition of secondary dentin. Kvaal et al. [3] conducted the first age estimation study that used periapical radiographs of unextracted teeth and suggested a method for measuring the length and width of the pulp chamber in the dental radiographs of people aged more than 20 years. The relationship between pulp chamber and tooth measurements was associated with age, and equations were developed to estimate age. Other studies [4] have performed age estimation among Brazilian adults using periapical $\mathrm{x}$-rays, but Kvaal et al. [3] technique was not performed in this population yet.

The present study aims to report two cases of age estimation using the method developed by Kvaal et al. [3] in living Brazilian older adults.

\section{CASE DESCRIPTION}

The Prosecutor's Office for Defending Human Rights of the Public Ministry of the State of Rio Grande do Sul (Brazil) referred two apparently older, undocumented, lowincome males to the health service (Serviço Biomédico) of the Public Ministry of the State of Rio Grande do Sul for age estimation tests.

The dental age estimation method recommended by Kvaal et al. [3] was used in both cases to estimate an age range containing an individual's chronological (real) age. The method uses a specific formula for the dental elements, with an error margin of 11.5 years. After this stage, new civil records were made, entitling the cases to some social benefits.

Permission for these cases report was obtained from the Public Ministry of the State of Rio Grande do Sul - Brazil (approval number 116/2008).

\section{CASe 1}

Examination of the oral cavity of Mr. F.L. showed that he had only two teeth on the lower dental arch: left and right canines, 33 and 43, respectively, according to the International Dental Federation (FDI) notation. The elements had shallow carious lesions on the crown and root - some of them small - and periodontal disease, with bone resorption, root exposure, and tartar. Two periapical radiographs were taken on the same day of the dental examination (Figure 1) for adult age estimation. The age estimation equation for tooth 33 indicated an age of 58 years and 2 months, and for tooth 43, 62 years and 1 month. Thus, the individual has an estimated mean age of 60 years and 1 month, ranging from 54 years and 3 months to 65 years and 8 months.

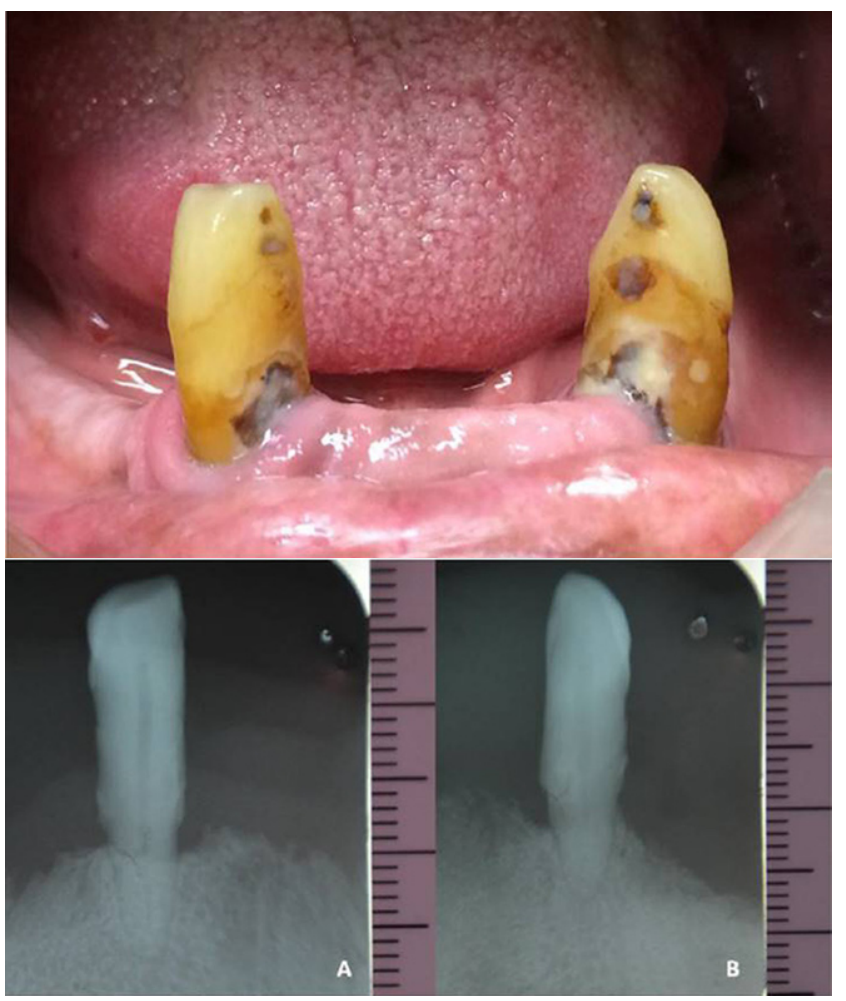

Figure 1. Frontal view of the lower dental arch showing the vestibular and mesial surfaces of teeth 43 and 33, with completely formed roots, closed root apex, and incisal wear.

\section{CASE 2}

Mr. J.L.S. had only three teeth on the lower dental arch: left mandibular central incisor (31), left mandibular lateral incisor (32), and left mandibular canine (33), according to the FDI notation. The elements were healthy but had some wear on the incisal surface and slight palatine and interproximal staining. There was no periodontal disease. A periapical radiograph was taken on the same day of the dental examination (Figure 2) for adult age estimation. The age estimation equation for tooth 32 indicated an age of 63 years and 6 months, ranging from 57 years and 6 months 
to 69 years and 3 months in May of 2014. Although tooth 33 could be assessed by the method, it was not assessed because it was slightly rotated, a method bias. The technical assistants were surprised to learn that there was a document in the medical record, supplied by the representative of the municipal shelter, with a birth date of May 12, 1955, when the case was treated at a local hospital in 2013 at age 58 years, approximately (Figure 2). The estimated age is compatible with the date in the hospital admission form.

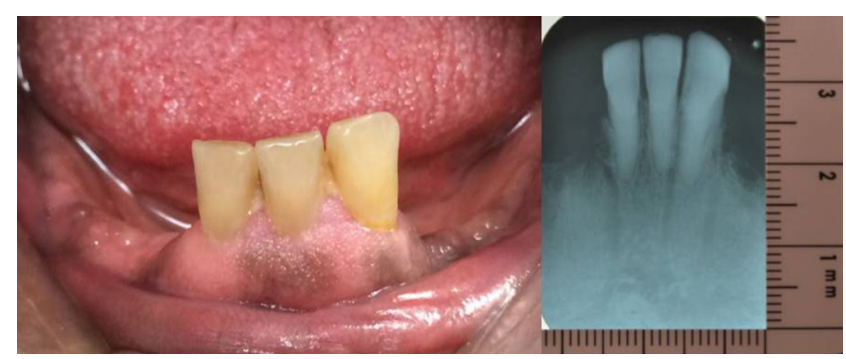

Figure 2. Frontal view of the lower dental arch showing the vestibular surfaces of teeth 31,32 , and 33 , and a periapical radiograph showing the healthy elements 31,32 , and 33 , with fully formed roots and closed root apex

\section{DISCUSSION}

According to Liversidge \& Marsden [5], dental age estimation is generally requested in forensic cases of bone remains, mass disasters, children without birth certificates, and asylum seekers, and used in the fields of archeology and anthropology. Santoro et al. [1] also mention a demand for dental age estimation related to higher immigration secondary to globalization and armed conflicts.

Age estimation is very important because old age entitles individuals to receive State aid, and younger people are more likely to receive smaller punishments for criminal activities. Individuals may lose or have never had identity documents, or may be genuinely unaware of their chronological age, or unwilling to disclose their age for a number of reasons. The absence of legitimate documents compromises a citizen's rights and duties. Hence, when age estimation is necessary, authorities seek the experience of professionals to guide and assist them, allowing them to make the best decision [1]. People with specialized training and forensic experience are recommended.

The physical assessment and the use of radiographic methods based on the narrowing of the pulp chamber caused by the formation of secondary dentin - a continuous and regular process due to physiological and pathological reasons - are recommended for age estimation [4]. The use of radiographs makes the technique: non-destructive, fast, inexpensive, repeatable, easily executable, and easy to be compared by different observers. The method developed by
Kvaal et al. [3] uses this theoretical basis - morphological and radiological - for age estimation in adults. However, its accuracy should be checked in different populations. Before forensic dentists use an age estimation method, they should examine the oral cavity and dental conditions whenever possible as this stage complements scientific methods [2].

Based on the method developed by Kvaal et al. [3], the study cases have most probable ages ranging from 54 years and 3 months to 65 years and 8 months for case 1 , and from 57 years and 6 months to 69 years and 3 months for case 2 . Given that ancestry aspects, socioeconomic level, and diseases potentially influence one's development, the results should be taken with caution because of the limitations, such as caries on the crown and root of the dental elements of case 1 , and the use of a formula developed for Norwegians, and both study cases (1 and 2) are Brazilian. However, both the Norwegian and Brazilian cases have low socioeconomic level.

Although the formula provided an acceptable result in the original study, the use of the formula in different populations is questioned. Considering that a medical record containing the age of case 2, 57 years old in 2013, is accurate, ancestry did not negatively influence the result in Brazilians, since the real age is within the estimated range. The method also highlights the importance of estimating an age range instead of a specific age.

\section{CONCLUSION}

In conclusion, the technique developed by Kvaal et al.[3] can be used in Brazilians providing the ethical and legal principles for establishing the best age estimate are followed. The limitations of this technique based on retrogressive dental changes should be clear to the legal authorities, and professionals must use technical and scientific arguments to justify the result.

\section{REFERENCES}

1. Santoro V, De Donno A, Marrone M, Campobasso CP, Introna F. Forensic age estimation of living individuals: a retrospective analysis. Forensic Sci Int. 2009; 193(1-3):129.e1-4. https://doi.org/10.1016/j.forsciint.2009.09.014

2. Cunha E, Baccino E, Martrille L, Ramsthaler F, Prieto J, Schuliar Y, Lynnerup $\mathrm{N}$, Cattaneo $\mathrm{C}$. The problem of aging human remains and living individuals: a review. Forensic Sci Int. 2009;193(1-3):1-13. https://doi:10.1016/j. forsciint.2009.09.008

3. Kvaal SI, Kolltveit KM, Thomsen IO, Solheim T. Age estimation of adults from dental radiographs. Forensic Sci Int. 1995;74(3):175-85.

4. Azevedo AC, Alves NZ, Michel-Crosato E, Rocha M, Cameriere R, Biazevic MG. Dental age estimation in a Brazilian adult population using Cameriere's method. Braz Oral Res. 2015;29(1):1-9. https://doi:10.1590/18073107BOR-2015.vol29.0016

5. Liversidge HM, Marsden PH. Estimating age and the likelihood of having attained 18 years of age using mandibular third molars. Br Dent J. 2010; 209(8):E13. https://doi: 10.1038/sj.bdj.2010.976 